\title{
Cryopreservation of coffee zygotic embryos: dehydration and osmotic rehydration
}

\section{Criopreservação de embriões zigóticos de cafeeiro: desidratação e reidratação osmótica}

\author{
Maísa de Siqueira Pinto ${ }^{1 *}$, Renato Paiva², Diogo Pedrosa Corrêa da Silva², \\ Paulo Augusto Almeida Santos ${ }^{3}$, Rodrigo Therezan de Freitas², Luciano Coutinho Silva ${ }^{4}$
}

\author{
1Universidade de São Paulo/USP, Escola Superior de Agricultura "Luiz de Queiroz"/ESALQ, Departamento de Ciências Biológicas, Piracicaba, SP, Brasil \\ ${ }^{2}$ Universidade Federal de Lavras/UFLA, Lavras, MG, Brasil \\ ${ }^{3}$ Universidade Federal de Sergipe/UFSE, Aracaju, SE, Brasil \\ ${ }^{4}$ Universidade Federal da Paraíba/UFPB, João Pessoa, PB, Brasil \\ *Corresponding author: maisadesiqueira@gmail.com \\ Received in March 1, 2016 and approved in May 24, 2016
}

\begin{abstract}
Conservation of plant genetic resources is important to prevent genetic erosion. Seed banks are the most common method of ex situ conservation; however, coffee seeds can not be stored by conventional methods. Cryopreservation is a viable alternative for long-term conservation of species that produce intermediate or recalcitrant seeds, as coffee. The aim of this work was to cryopreserve Coffea arabica L. cv Catuaí Vermelho IAC 144 zygotic embryos, and analyse the effects of dehydration prior cryopreservation and osmotic rehydration after thawing, in embryos germination and seedlings formation after cryopreservation. Prior to cryopreservation, different dehydration times $(0,15,30,60$ and $120 \mathrm{~min})$ were tested. Dehydrated embryos were cryopreserved in liquid nitrogen for 1 hour, and after thawing were rehydrated by osmotic solutions. Dehydrated and non-cryopreserved embryos were also analysed. The test with 2,3,5 triphenyl tetrazolium chloride (TTC) was used to evaluate the embryos viability. Non-dehydrated embryos did not survive after freezing. Embryos that were dehydrated until $20 \%$ of the moisture content did not germinate when osmotic rehydration was not performed. In contrast, cryopreserved embryos with the same moisture content presented $98 \%$ germination when they were rehydrated slowly in osmotic solution. According to tetrazolium tests, embryos presented maximum viability (75\%) after dehydration for 60 minutes (23\% moisture content). Therefore, coffee zygotic embryos (Coffea arabica L. cv. Catuaí Vermelho) can be successfully cryopreserved using physical dehydration in silica gel for 60 minutes ( $23 \%$ moisture content), followed by osmotic rehydration after thawing. This method allowed a germination of $98 \%$ of cryopreserved zygotic embryos.
\end{abstract}

Index terms: Coffea arabica L.; ex situ conservation; embryos dehydration; long-term storage; gene bank.

\begin{abstract}
RESUMO
A conservação dos recursos genéticos vegetais é uma medida importante para prevenção do processo de erosão genética. Bancos de sementes são as formas mais comuns de conservação ex situ, entretanto, sementes de cafeeiro não podem ser armazenadas por métodos convencionais. A criopreservação é uma alternativa viável para conservação em longo prazo de espécies, como o cafeeiro, que produzem sementes intermediárias ou recalcitrantes. O objetivo deste trabalho foi criopreservar embriões zigóticos de Coffea arabica L. cv Catuaí Vermelho avaliando o efeito da desidratação antes da criopreservação, e da reidratação osmótica após o descongelamento. Antes da criopreservação foram testados e determinados os teores de umidade em diferentes tempos de desidratação $(0,15,30,60$ e 120 min). Após a desidratação os embriões foram criopreservados por uma hora em nitrogênio líquido, e após o descongelamento foram reidratados utilizando solução osmótica. Para avaliação da viabilidade de embriões desidratados e/ou criopreservados, utilizou-se o teste com o cloreto de 2,3,5-trifenil tetrazólio. Embriões não desidratados não sobreviveram ao congelamento. Embriões desidratados até cerca de 20\% de umidade que não passaram por uma reidratação osmocondicionada, não germinaram. Embriões desidratados até cerca de $20 \%$ de umidade, criopreservados e reidratados lentamente após o descongelamento, apresentaram $98 \%$ de germinação. A máxima viabilidade obtida através do teste de tetrazólio foi $75 \%$ após 60 minutos de desidratação. Portanto, embriões zigóticos de cafeeiro podem ser criopreservados utilizando desidratação física em sílica gel por 60 minutos ( $23 \%$ de teor de umidade), seguida de reidratação com solução osmótica após o descongelamento. Esse método permitiu a germinação de $98 \%$ dos embriões criopreservados.
\end{abstract}

Termos para indexação: Coffea arabica L.; conservação ex situ; desidratação de embriões; conservação por tempo prolongado; banco de germoplasma. 


\section{INTRODUCTION}

Cryopreservation is the storage of living biological material at ultralow temperatures. This technique is considered safe and economically viable for the long-term conservation of many plant species that are difficult to store using traditional methods. In ultralow temperatures, as in liquid nitrogen $\left(-196^{\circ} \mathrm{C}\right)$, cell division and metabolic processes are dramatically disrupted, allowing material storage without any alteration for, in theory, an unlimited period. Other advantages of this technique are the small space needed for storage, the absence of possible contaminants and low maintenance requirements (Folgado et al., 2015; Maslanka; Panis; Malik, 2016; Engelmann, 2004; Silva et al., 2013).

The success of cryopreservation lies in a controlled dehydration and water crystallisation during freezing, thus avoiding lethal damage to membranes and cellular organelles (Wesley-Smith, 2014; Seidel, 1996). This damage occurs mainly due to water's characteristics of expansion during freezing and to the conformation of water ice crystals. Some substances are capable of avoiding crystallisation when cooled in a temperature far below its melting point (Engelmann, 2004). The formation process of this amorphous solid is known as vitrification (Kaviani, 2011). The super-cooled material maintains its liquid characteristics until reaching vitrification temperature. Below this temperature, the water molecules remain disordered as in the liquid state. However, its physical properties resemble those of a rigid solid. This is an important process for cryobiology because liquid water in its natural state is disordered within the living organisms, and the maintenance of this natural disorder is advantageous due to the minimal disturbance of the system being preserved (Folgado et al., 2015; Wowk, 2010).

The glassy state is reached by increasing cellular liquid content viscosity and by a fast cooling of the system. Therefore, a previous dehydration of the material before freezing is important to increase internal solute viscosity to reach the glassy state. This is a delicate process since an excessive desiccation leads to membrane lipid peroxidation and irreversible loss of semipermeability (Pukacki; Juszczyk, 2015). A high survival level is usually achieved when the samples are frozen at a moisture content of $10 \%$ to $20 \%$ (Engelmann, 2004; Wowk, 2010).

Several cryopreservation techniques have been already established, and the freezing process can occur quickly or slowly (Engelmann, 2004). In rapid freezing, explant dehydration occurs before exposure to liquid nitrogen. This dehydration can be carried out by physical methods such as exposing the sample to a laminar flow cabinet. However, the dehydration is more uniform and efficient when using a closed system containing silica gel (Sisunandar et al., 2010). Thus, most of the intracellular water is removed before rapid freezing in liquid nitrogen, inducing the vitrification of the sample solutes (GonzalezArnao et al., 2008). The great advantage of this method is that the material can be preserved directly into liquid nitrogen after dehydration without using cryoprotectants, which can present cytotoxicity (Engelmann, 2004; Gonzalez-Arnao; Engelmann, 2004). Physical dehydration is widely used to cryopreserve orthodox seeds and zygotic embryos (Souza et al., 2014; Moreira et al., 2014). However, rapid and controlled dehydration can be used to cryopreserve zygotic embryos of some plant species that present recalcitrant seeds (Al Zoubi; Normah, 2015; Panis; Lambardi, 2006).

Another critical step of plant cryopreservation protocols is the thawing of the explant after liquid nitrogen exposure, caused mainly by the formation of larger ice crystals of lethal dimensions during warming (WesleySmith et al., 2015). The rate of thawing and the nature of the medium in which explants are warmed and then rehydrated is critical to the recovery of the explant after cryopreservation (Wesley-Smith et al., 2015; Berjak; Pammenter, 2014)

Coffee seeds exhibit little longevity during conventional storage according Dussert et al. (1997). Furthermore, coffee germplasm conservation in field genebanks ex situ or in vitro is very expensive. Comparative research between the largest field genebank and the coffee cryocollection of the Tropical Agricultural Research and Higher Education Center (CATIE) in Costa Rica has shown that cryopreservation is more economically advantageous for long-term conservation (Dulloo et al., 2009).

Seeds, somatic and zygotic embryos are used in the research for the development of coffee cryopreservation techniques. However, only studies regarding the cryopreservation of coffee seeds were efficient to allow its routine use in genebanks (Dussert; Engelmann, 2006; Etienne et al., 2002).

The aim of this work was to cryopreserve Coffea arabica L. cv Catuaí Vermelho IAC 144 zygotic embryos, and analyse the effects of dehydration prior cryopreservation and osmotic rehydration after thawing, in the embryos germination and seedlings formation after cryopreservation. 


\section{MATERIALS AND METHODS}

\section{Zygotic embryos excision}

Coffea arabica L. Catuaí Vermelho IAC 144 was chosen due to its high agronomic performance, being widely cultivated in the south of Minas Gerais (Lima et al., 2016). Before the excision of the zygotic embryos, seeds had the parchment removed and were decontaminated using $70 \%$ ethanol for one minute followed by sodium hypochlorite ( $2.5 \%$ active chlorine) for 30 minutes. The seeds were rinsed three times and then soaked in sterile water for 24 hours in closed glass flasks. After soaking, in a laminar flow cabinet, the seeds were again decontaminated using $70 \%$ ethanol and sodium hypochlorite $(2.5 \%$ active chlorine) for the same amount of time as described above before being rinsed three times in sterile water (Andrade et al., 2001). Embryos were excised with the aid of tweezers and a scalpel and were maintained in $200 \mathrm{mg} \mathrm{L}^{-1}$ polyvinylpyrrolidone (PVP) solution until the excision of all embryos prior to the dehydration experiments.

\section{Dehydration, cryopreservation and rehydration of zygotic embryos}

Embryo dehydration was carried out by physical methods in a closed container (Gerbox ${ }^{\circledR}$ ) containing $68 \mathrm{~g}$ of silica gel for $0,15,30,60$ and 120 minutes. Twenty-four embryos were used for each dehydration time: 12 for control treatments and 12 for cryopreservation treatments. Each replicate consisted of a test-tube $(25 \times 150 \mathrm{~mm})$ containing a zygotic embryo. The embryo moisture content (\%) was assessed using five replicates composed of five zygotic embryos for each dehydration time. The followed formula was used to determine the embryos moisture content: $\mathrm{MC} \%=(($ wet weight - dry weight $) \times 100)) /$ wet weight.

Prior to cryopreservation, embryos dehydrated for different periods were transferred to $2.0 \mathrm{~mL}$ closed cryotubes and plunged into liquid nitrogen (LN), where they remained for 24 hours. After this period, the cryotubes were immersed in a water bath and the embryos were thawed for three minutes at $40 \pm 2{ }^{\circ} \mathrm{C}$. After thawing, the embryos underwent a slow rehydration (osmotic rehydration) in a solution with high sucrose concentration. In each cryotube, $2.0 \mathrm{~mL}$ of liquid MS medium (Murashige; Skoog, 1962) supplemented with $1 \mathrm{M}$ sucrose was added for 30 minutes. After this period, $0.5 \mathrm{~mL}$ of rehydration solution was replaced every 10 minutes by $0.5 \mathrm{~mL}$ of MS liquid medium supplemented with $0.1 \mathrm{M}$ sucrose. This procedure was repeated three times as described by Steinmacher et al. (2007).
Only cryopreserved embryos were subjected to osmotic rehydration, and after that, embryos were cultured on MS basal medium and maintained in a growth room chamber under a $16 \mathrm{~h}$ photoperiod, with $36 \mu \mathrm{mol} \mathrm{m}^{-2} \mathrm{~s}^{-1}$ of irradiance at $25 \pm 2{ }^{\circ} \mathrm{C}$ temperature. Embryo germination, by means of radicle or shoot growth, was evaluated after seven days of culture, and the formation of seedlings with normal development was assessed after 30 days of culture. Only embryos that presented shoots and roots longer than $0.5 \mathrm{~cm}$ and with normal aspect were counted as normal seedlings.

\section{Viability of cryopreserved embryos}

To assess the viability after thawing and osmotic rehydration, the embryos were treated with a solution containing $0.1 \%$ of 2,3,5-triphenyl tetrazolium chloride (TTC) in the absence of light in a BOD incubator at $35^{\circ} \mathrm{C}$ for a period of 16 hours. After this period, the embryos were rinsed and maintained in sterile water prior to evaluation (Zonta et al., 2009).

The embryo staining intensity was evaluated using a stereoscopic microscope. Embryos were classified into three classes according to the staining displayed: (i) viable and vigorous (intact and completely coloured embryos in bright pink to red carmine); (ii) viable and non-vigorous (embryos that presented the radicle-tip and/or cotyledon uncoloured or fully coloured in deep red carmine); and (iii) inviable (embryos fully coloured with deep carmine, yellow or milky white). For the TTC staining test, five replicates with 10 zygotic embryos each were used for each dehydration time.

\section{Acclimatization}

Black plastic bags $(11 \times 20 \mathrm{~cm})$ were filled with a mixture (1:1) of a commercial substrate (Topstrato Florestal) and vermiculite for acclimatization. Seedlings were planted, and transparent plastic bags were used as cover to prevent excessive moisture loss from the seedlings after the transfer from in vitro to ex vitro environment. Every seven days, a cut of $1.0 \mathrm{~cm}$ in diameter was made in each plastic cover bag, allowing higher gas exchange to provide adaptation to the natural environment with lower air relative humidity. After 35 days of acclimatization, the plastic cover bag was removed completely.

Seedlings originating from (i) non-dehydrated embryos (control); (ii) embryos dehydrated for 30 minutes and not cryopreserved; or (iii) embryos dehydrated for 60 minutes and then cryopreserved, were acclimatized. Ten replications per treatment were used, and each seedling was considered as a replication. Shoot 
length, number of leaves, seedling survival and seedling fresh weight were evaluated 35 days after the beginning of the acclimatization process.

\section{Statistical analysis}

A completely randomised design was used for all experiments. The data were analysed using ANOVA in the statistical package SISVAR (Ferreira, 2014), and the means were tested using Tukey's test $(P \leq 0.05)$.

\section{RESULTS AND DISCUSSION}

\section{Dehydration and germination of non- cryopreserved zygotic embryos}

The initial moisture content of non-dehydrated embryos was $61.3 \%$. After 60 minutes of dehydration in silica gel, the moisture content decreased rapidly to $23 \%$ and then slowly until reaching $20 \%$ at the end of 120 minutes (Figure 1A).

The two-phase dehydration pattern observed in Figure $1 \mathrm{~A}$, with a rapid initial decrease in the moisture content followed by a slower dehydration, is reported regarding dehydration of zygotic embryos from different plant species such as Haemanthus montanus (Sershen; Pammenter; Berjak, 2011), Cocos nucifera L. (Sisunandar et al., 2010), Byrsonima intermedia (Silva et al., 2014) and Amaryllis belladonna (Ballesteros et al., 2014). However, differences in the period of dehydration among species, and even among cultivars, may be observed mainly due to the differences in embryo formation and morphology, and the time to reach the suitable embryo moisture content for cryopreservation depends on the inherent chemical and physical characteristics of each species (Ballesteros et al., 2014; Sershen; Pammenter; Berjak, 2011).

The dehydration curve obtained for zygotic embryos in this work is similar to the curve obtained for coffee seeds. In both of them, during the first few hours of dehydration, there is a rapid decrease in the moisture content from $80 \%$ to $25 \%$, and in the final hours, the moisture content decreases slowly until reaching $15 \%$. Although, there is a difference in the time required to reach 25 and $15 \%$ moisture content between seeds ( 6 and 16 hours, respectively) and embryos (1 and 4 hours, respectively) (Dussert et al., 1998).
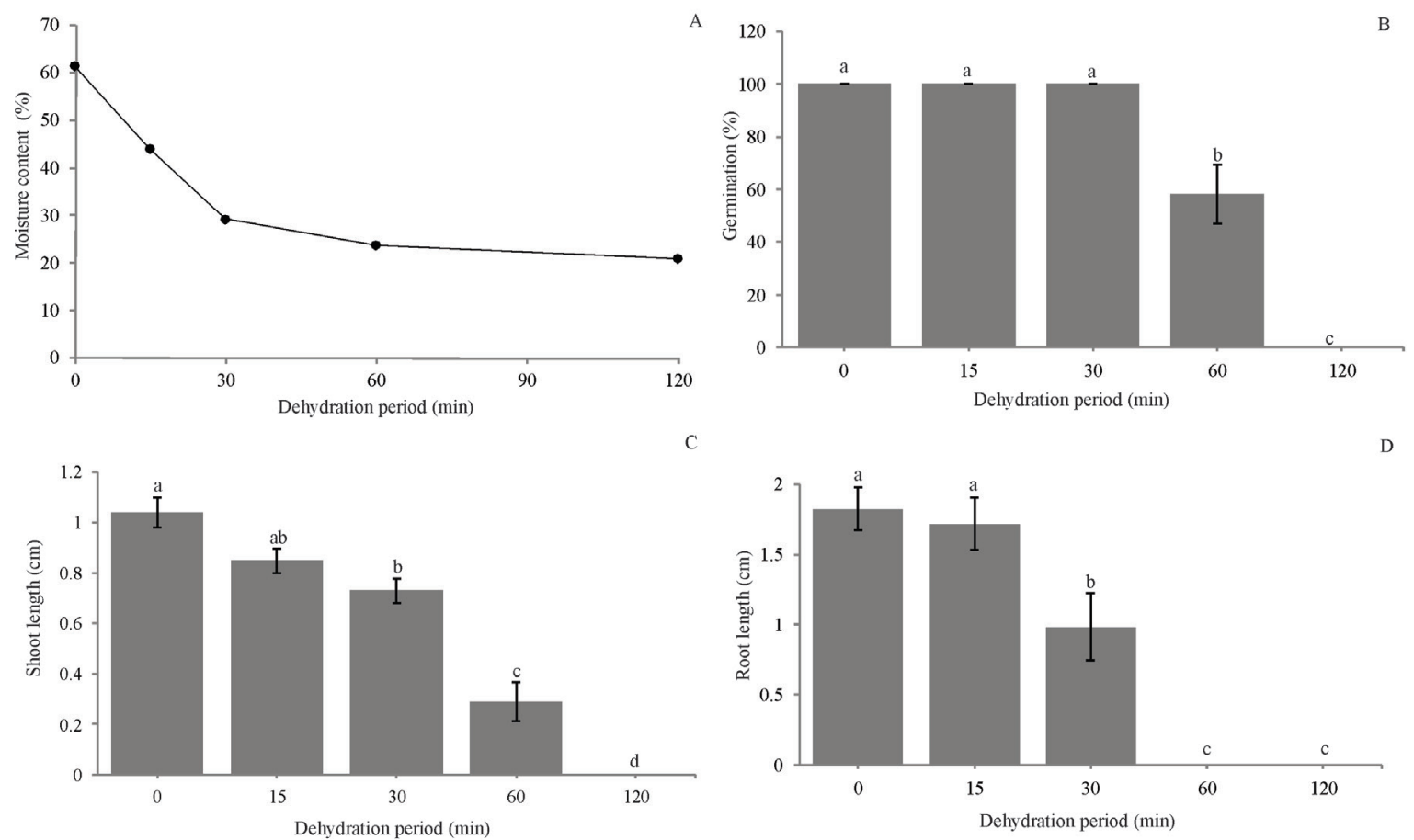

Figure 1: Moisture content of Coffea arabica L. CV. Catuaí Vermelho zygotic embryos after silica gel dehydration for different times (A). Germination (radicle or shoot growth) of dehydrated embryos after seven days of in vitro culture on MS medium (B). Shoot (C) and root (D) length of seedlings obtained from the germination of dehydrated zygotic embryos after 30 days of in vitro culture on MS medium. 
Zygotic embryo germination was significantly affected $(p<0.001)$ by the dehydration time (Figure 1B). The germination percentage after 30 minutes was $100 \%$, and embryos presented a $29 \%$ moisture content. However, when the moisture content decreased to $23 \%$, after 60 minutes of dehydration, a significant drop in embryo germination (58\%) was observed. Embryos dehydrated for 120 minutes (21\% moisture content) were severely affected by the low moisture content and did not survive. Coffea arabica L. cv. Caturra zygotic embryos extracted from freshly harvested fruit presented $25 \%$ survival when dried to $10 \%$ moisture content in a laminar flow cabinet (Abdelnour-Esquivel; Villalobos; Engelmann, 1992). The difference in embryo desiccation tolerance may be due to inherent differences in cultivars and the seed status during embryo excision. The stage of embryo maturity is related to the cryopreservation success and may be species dependent (Sisunandar et al., 2014). Moreover, dehydrated and noncryopreserved embryos did not follow a slow rehydration pattern in a solution with a high sucrose concentration.

Seedling development after germination was also significantly affected by the period of embryo dehydration for both, shoot $(p<0.001)$ and root growth $(p<0.001)$. The longer the dehydration time was, the shorter was the shoot or root length (Figure 1C, D). After 60 minutes of dehydration (embryos with $23 \%$ moisture content), a drastic reduction in the shoot length (Figure 1C) was observed. These seedlings were abnormal, presenting no roots (Figure 1D).

\section{Cryopreservation of zygotic embryos}

Compared with dehydrated and non-cryopreserved embryos (Figure 1B), the osmotic rehydration in a solution with a high sucrose concentration was essential for the survival/ germination of dehydrated and cryopreserved embryos, especially after 60 and $120 \mathrm{~min}$ of dehydration (Figure 2).
The lack of osmotic rehydration in dehydrated and non-cryopreserved embryos (Figure 1B) allowed the soaking to occurs quickly, which may have caused damage to the cell membrane. Dussert et al. (2000) highlighted the benefit of osmotic rehydration after the thawing of coffee seeds (Coffea arabica L.), which was able to promote an increase in the germination rate from $16 \%$ (seeds without osmotic rehydration) to $74 \%$ (seeds with osmotic rehydration). Non-dehydrated embryos did not survive following cryopreservation, but the germination percentage increased, reaching a maximum of $98 \%$ after 120 minutes of dehydration (Figure 2A), with a 21\% moisture content.

The presence of high water content in the cells favours the formation of ice crystals, which causes lethal damage to membranes and, consequently, cell death during freezing (Wesley-Smith et al., 2015; Mazur, 1984). The decrease in intracellular water reduces the chances of water crystallisation; thus, the germination of cryopreserved embryos increased (Figure 2A) as the moisture content decreased (Figure 1B). Dehydration increases the solute concentration, leading to the formation of the glassy state following a rapid freezing. In the glassy state, an amorphous system, that presents the same physical and mechanical properties of a solid, is formed, enabling the survival of the embryos (Wowk, 2010). A successful glassy state was reached during freezing after dehydration for 60 and 120 minutes, where high germination percentages (Figure 2A) and normal seedlings formation, 75 and $67 \%$ respectively, were observed (Figure 2B). However, after 120 minutes of dehydration, some abnormal seedlings formation was observed (Figure 3C, D), although, there was no statistical difference in normal seedlings formation between zygotic embryos dehydrated for 60 and 120 minutes.
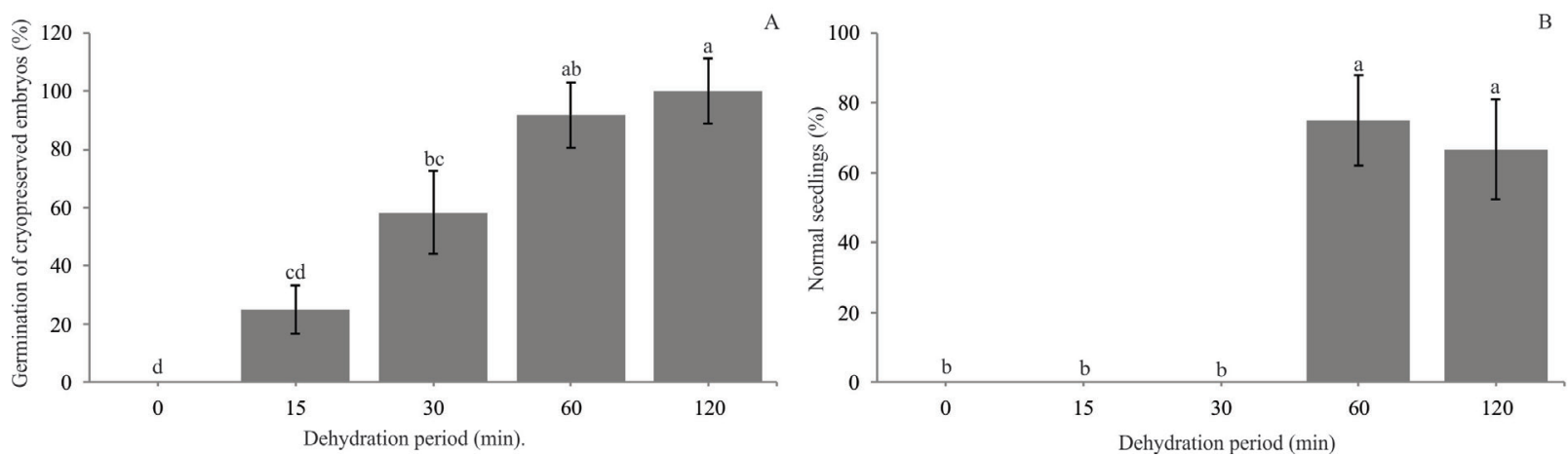

Figure 2: Cryopreservation of Coffea arabica L. Cv. Catuaí Vermelho zygotic embryos after dehydration in silica gel for different times and maintained in liquid nitrogen $\left(-196^{\circ} \mathrm{C}\right)$ for 24 hours. Germination percentage (radicle or shoot growth) after seven days of in vitro culture (A). Normal seedling formation after 30 days of in vitro culture (B). 

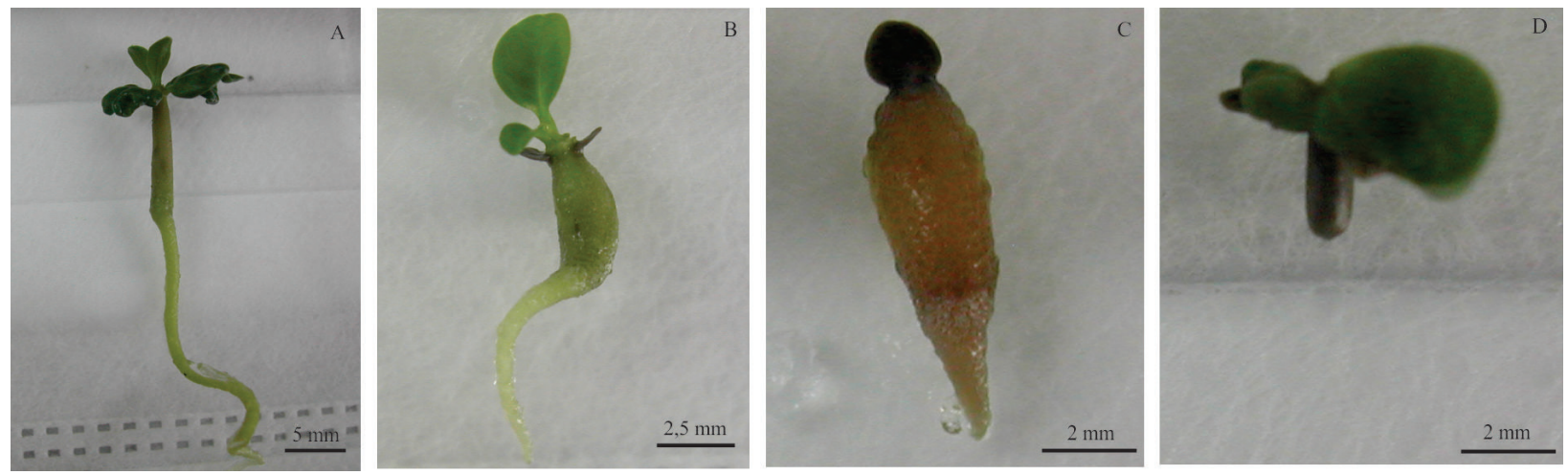

Figure 3: Germination of Coffea arabica L. cv. Catuaí Vermelho embryos. Normal seedling originating from a fresh and non-cryopreserved embryo (A). Normal seedling originating from a cryopreserved embryo after 60 minutes of dehydration (B). Absence of shoot (C) or root (D) formation on seedlings originating from cryopreserved embryos after 120 minutes of dehydration.

\section{Viability of cryopreserved embryos using TTC}

The highest viability $(76 \%)$ according to the TTC test was observed in embryos after 60 minutes of dehydration (Figure 4A). However, the embryo vigour (Figure 4E) was extremely low (26\%) after 60 minutes of dehydration (Figure 4B), showing that small cell damages may have occurred. Nonetheless, the embryo regrowth was not compromised and high germination and normal seedling percentages were obtained after 60 minutes of dehydration (Figure 2).

The tissue recovery after cryopreservation / thawing involves complex events such as the regeneration of the damaged tissue and the resumption of the cell metabolism until seedling formation (Salaj et al., 2016; Sershen et al., 2011). The ability of damaged tissues to recover after thawing may explain the differences in embryo viability with low moisture content, evaluated by the in vitro germination test and the TTC test. The TTC test provides a rapid response of the explant survival relative to dehydration time and efficiency of cryopreservation. However, this test should be used with caution, because the final assessment of viability is only possible by analysis of embryo germination and normal seedling formation (Normah; Makeen, 2007).

An inviable and non-vigorous embryo can be observed in figure $4 \mathrm{C}$, with a greyish colour, which indicates low activity of dehydrogenase enzymes involved in respiration and reduction of TTC. In the embryos that presented a pinkish red colour, viable but not vigorous (Figure 4D) and viable and vigorous (Figure 4E), the high activity of dehydrogenases reducing the TTC and producing the red colouring compound (formazan) in living cells, reflecting its efficient respiratory activity (Deswal; Chand, 1997), can be observed.

\section{Seedling acclimatization}

The root length of seedlings originated from cryopreserved embryos $(5.6 \mathrm{~cm})$ was statistically higher compared to seedlings originated from control $(4.5 \mathrm{~cm})$ or dehydrated and non-cryopreserved embryos (4.6 $\mathrm{cm}$ ) (Figure 5A). Regarding the number of roots, a significant difference among treatments before or after acclimatization was not observed. The shoot length before acclimatization showed significant differences between the control $(1.7 \mathrm{~cm})$ and the dehydrated and non-cryopreserved embryos (1.4 cm) (Figure 5B). After 35 days of acclimatization, the shoot length of cryopreserved embryos $(2.4 \mathrm{~cm})$ was statistically higher when compared to dehydrated and non-cryopreserved embryos $(1.9 \mathrm{~cm})$ (Figure 5B). Regarding the number of leaves, no significant difference was observed, yielding an overall average of 9.3 leaves per explant (data not shown). Dehydrated and cryopreserved embryos presented a significant difference regarding the fresh weight of seedlings $(253 \mathrm{mg}$ ) after 35 days of acclimatization compared to dehydrated and noncryopreserved embryos (137 mg) (Figure 5C).

The enhanced root growth in seedlings coming from cryopreserved embryos may be due to the osmotic rehydration after thawing, since only dehydrated and cryopreserved embryos had this treatment. The beneficial effect of controlled rehydration after cryopreservation in the germination of the seeds, and the percentage of normal seedlings formed, was already observed in Coffea arabica L. (Dussert et al., 2000). Besides that, in many crops the beneficial effect of osmopriming in seed germination and seedling vigour was observed under stress condition (Murthy; Tejavathi, 2016; Arif et al., 2014; Galhaut et al., 2014). 

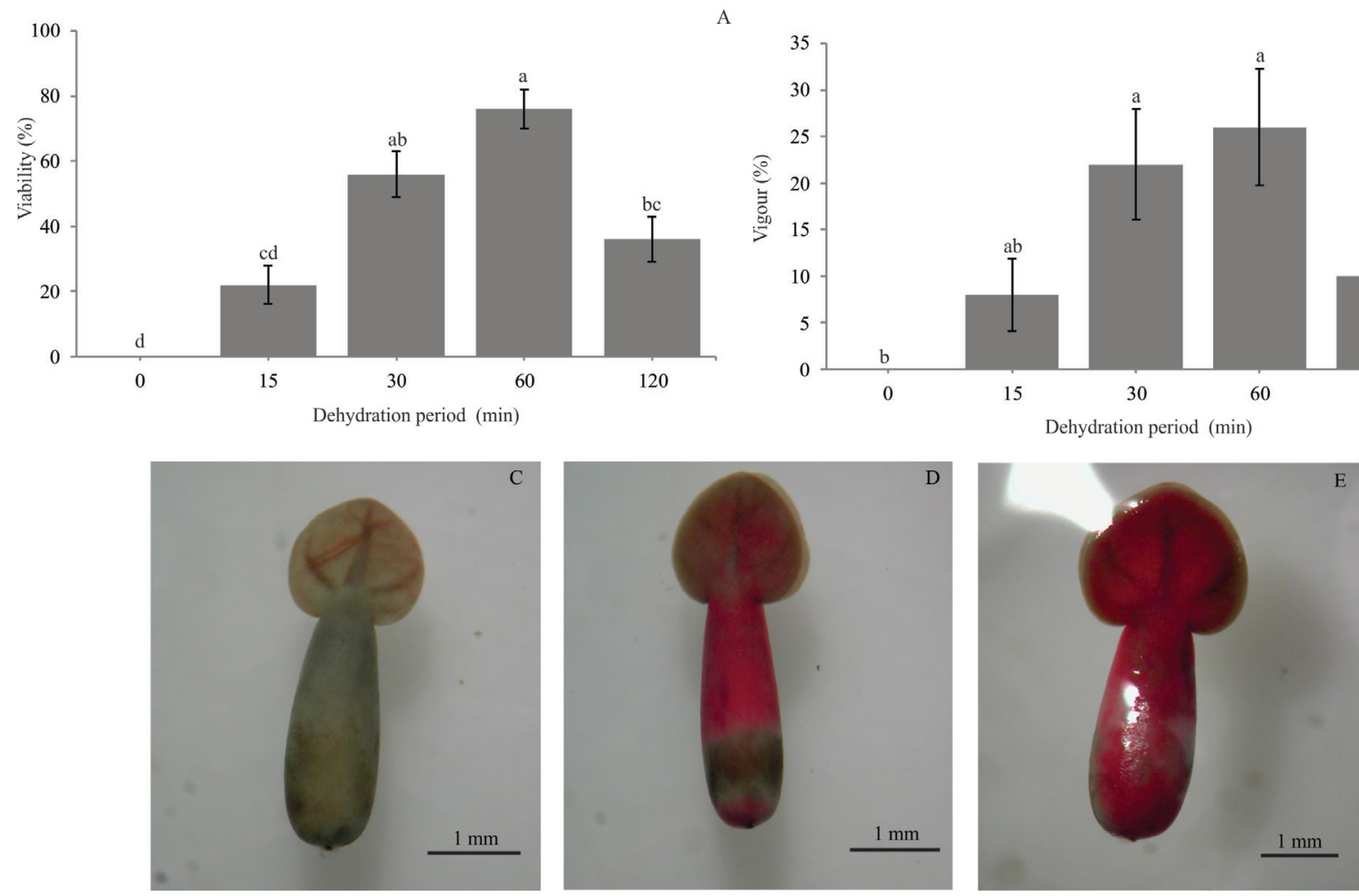

Figure 4: Viability (A) and vigour (B) of Coffea arabica L. CV. Catuaí Vermelho embryos treated with TTC after cryopreservation. Inviable embryo (C) after cryopreservation with absence of dehydration. Viable but not vigorous embryo after 120 min dehydration (D). Viable and vigorous embryo after 60 min of dehydration (E).

The freeze-thaw during cryopreservation procedure appears also to have impacts in seedling development. Nodal segments of asparagus, cryopreserved and osmotically rehydrated, had higher frequencies of root formation than the ones only treated with osmotic solution. The increased formation of roots in this case, may be due to physiological changes occurred in the tissues and/or cells of the cryopreserved nodal segments (Suzuki et al., 1998).

Seedlings of coconut (Cocos nucifera L.) originated from cryopreserved and dehydrated embryos, despite showing normal development during acclimatization, presented slower growth than the seedlings coming from fresh embryos (Sisunandar et al., 2010). However, in our study, no differences were observed in the shoot length, number of leaves, or roots among the seedlings originating from fresh embryos, dehydrated and non-cryopreserved embryos and dehydrated and cryopreserved embryos. Also, there were no phenotypic differences (leaf shape, colour or organ formation) among the above mentioned seedlings (Figure 6).
According to Fukai, Goi and Tanaka (1994), seedling development, in the greenhouse and in the field, must be monitored later because some phenotypic differences in reproductive organs after cryopreservation have been observed. However, the development of normal seedlings originated from dehydrated and cryopreserved coconut embryos described by Sisunandar et al. (2010) did not had phenotypic differences after 16 weeks of acclimatization. Moreover, Zevallos et al. (2014) also proved that until the second generation of wild Solanum lycopersicum Mill. no statistical significant differences were observed, regarding phenotype, between cryopreserved and non-cryopreserved samples.

This work presents a successful cryopreservation protocol of Coffea arabica L. cv. Catuaí Vermelho zygotic embryos with high survival and plant regeneration/ acclimatization percentages. Moreover, it was clear that the positive effect of the osmotic rehydration was crucial to ensure the survival of the embryos presenting low moisture content after cryopreservation. 

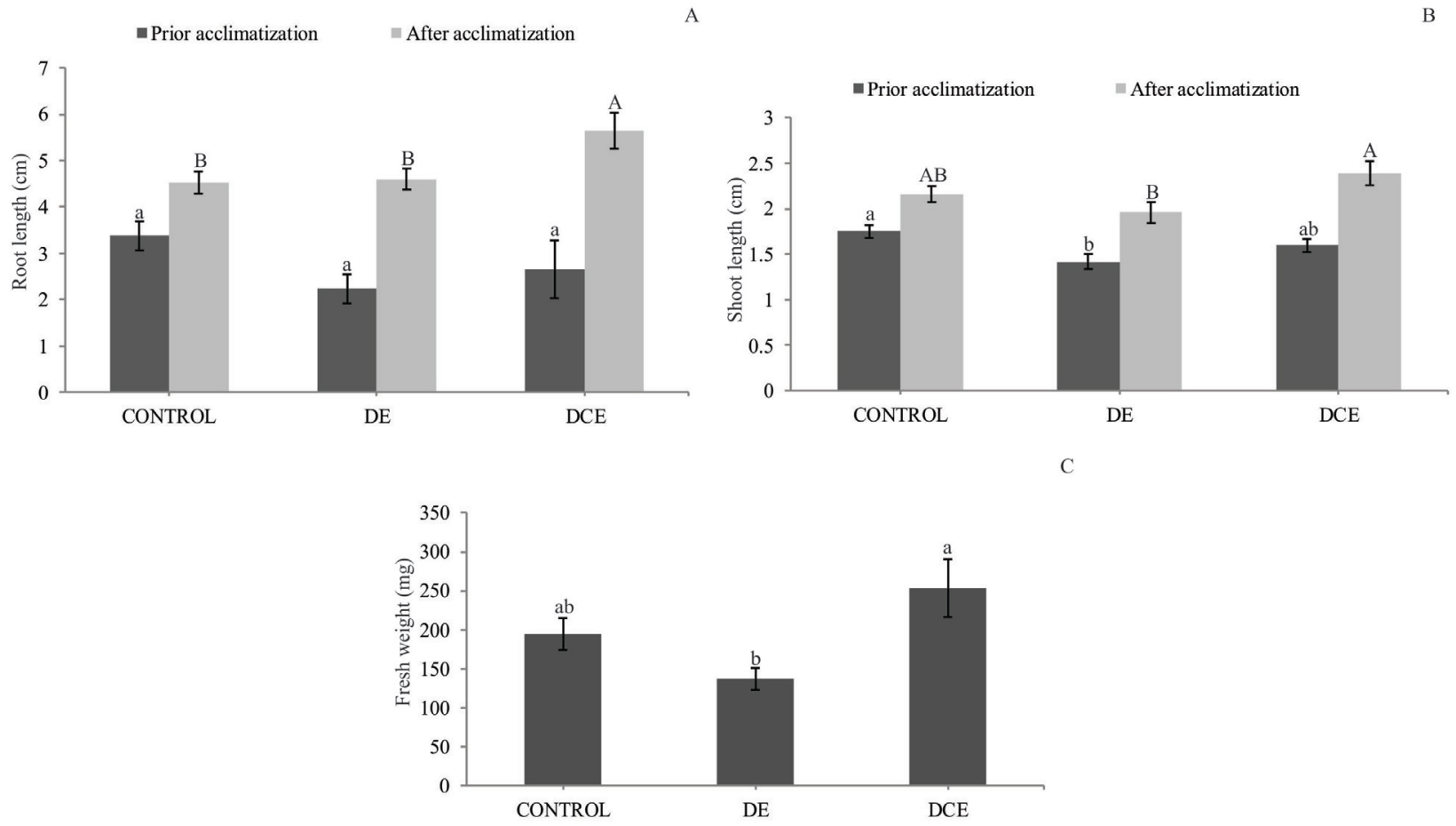

Figure 5: Root length (A), shoot length (B) and fresh weight (C) of Coffea arabica L. cv. Catuaí Vermelho seedlings originating from fresh (Control), dehydrated and non-cryopreserved embryo (DE), and dehydrated and cryopreserved embryo (DCE) before and after 35 days of acclimatization.
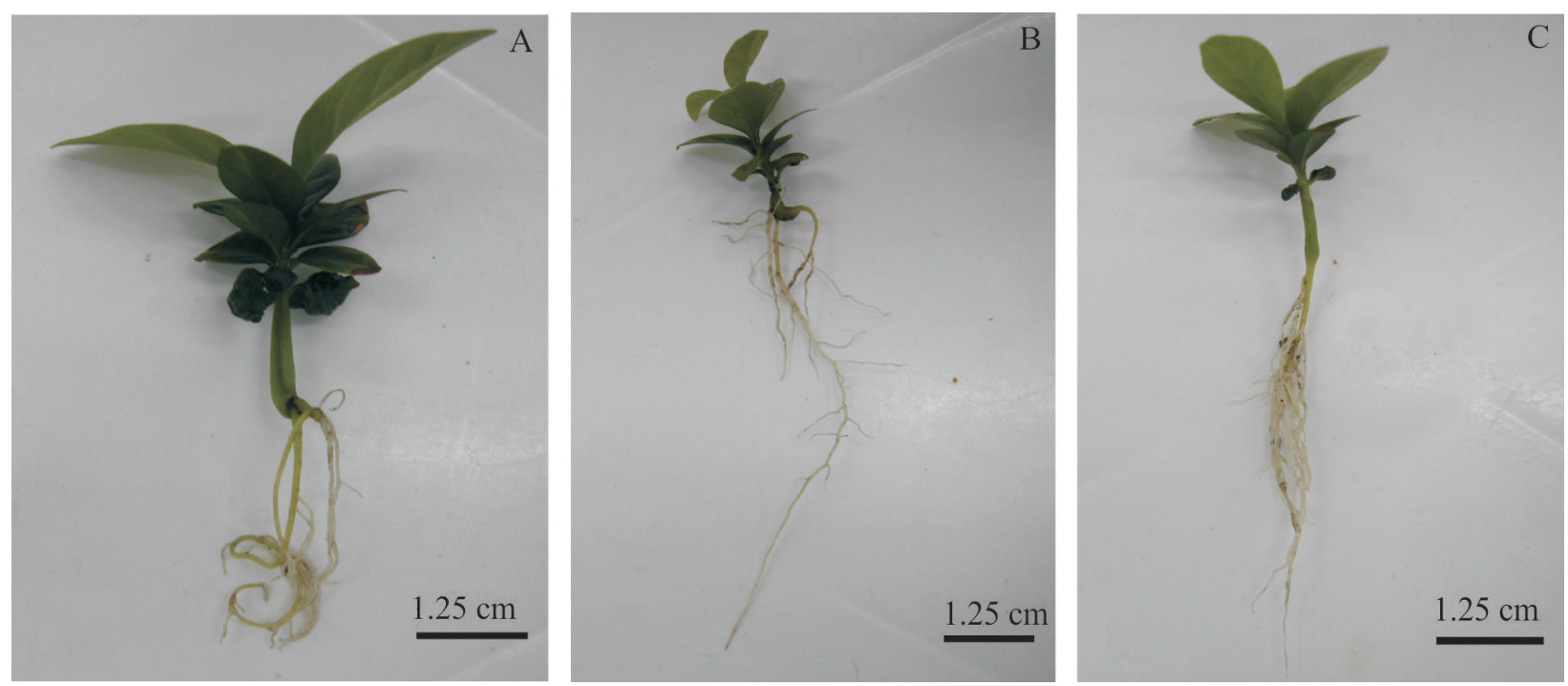

Figure 6: Coffea arabica L. cv. Catuaí Vermelho seedlings after 35 days of acclimatization. Seedling originating from fresh embryo (Control) (A), seedling originating from 30 min dehydrated and non-cryopreserved embryo (B) and seedling originating from 60 min dehydrated and cryopreserved embryos (C). 


\section{CONCLUSIONS}

Coffee zygotic embryos (Coffea arabica L. cv. Catuaí Vermelho) can be successfully cryopreserved using physical dehydration in silica gel for 60 minutes (23\% moisture content), followed by osmotic rehydration after thawing. This method allowed a germination of $98 \%$ of the cryopreserved zygotic embryos. Embryos dehydration is a crucial step before cryopreservation, since embryos that was not dehydrated did not survive after cryopreservation. Osmotic rehydration allowed the successful recovery of the embryos after cryopreservation. Seedlings originating from cryopreserved zygotic embryos were successfully acclimatized, reaching $100 \%$ survival.

\section{ACKNOWLEDGEMENTS}

To CNPq, CAPES and FAPEMIG for the financial support of this study and to the UFLA's Department of Agriculture Seed Sector for providing seeds.

\section{REFERENCES}

ABDELNOUR-ESQUIVEL, A.; VILLALOBOS, V.; ENGELMANN, F. Cryopreservation of zygotic embryos of Coffea spp. CryoLetters. 13:297-302, 1992.

AL ZOUBI, O. M.; NORMAH, M. N. Critical moisture content for successful cryopreservation of embryonic axes of Fortunella polyandra determined by differential scanning calorimetry (DSC). Acta Physiologiae Plantarum. 37(1727):1-15, 2015.

ANDRADE, L. M. C. O. et al. Cultura in vitro de embriões de Coffea arabica: influência de NAA e BAP. Ciência e Agrotecnologia. 5(5):1063-1070, 2001.

ARIF, M. et al. Evaluating the impact of osmopriming varying with polyethylene glycol concentrations and durations on soybean. International Journal of Agriculture and Biology. 16(2):359-364, 2014.

BALLESTEROS, D. et al. Uneven drying of zygotic embryos and embryonic axes of recalcitrant seeds: Challenges and considerations for cryopreservation. Cryobiology. 69(1):100-109, 2014.

BERJAK, P.; PAMMENTER, N. W. Cryostorage of germplasm of tropical recalcitrant-seeded species: approaches and problems. International Journal of Plant Sciences. 175(1):29-39, 2014.
DESWAL, D. P.; CHAND, U. Standardization of the tetrazolium test for viability estimation in rice bean [Vigna umbellata (Thunb.) Ohwi and Ohashi] seeds. Seed Science and Technology. 25(3):409-417, 1997.

DULLOO, M. E. et al. Cost efficiency of cryopreservation as a long-term conservation method for coffee genetic resources. Crop Science. 49(6):2123-2138, 2009.

DUSSERT, S. et al. Beneficial effect of post-thawing osmoconditioning on the recovery of cryopreserved coffee (Coffea arabica L.) seeds. CryoLetters. 21(1):47-52, 2000.

DUSSERT, S. et al. Cryopreservation of seeds of four coffee species (Coffea arabica, C. costatifructa, C. racemosa and C. sessiliflora): Importance of water content and cooling rate. Seed Science Research. 8:9-15, 1998.

DUSSERT, S. et al. Cryopreservation of coffee (Coffea arabica L.) seeds: Importance of the precooling temperature. CryoLetters. 18:269-276, 1997.

DUSSERT, S.; ENGELMANN, F. New determinants for tolerance of coffee (Coffea arabica L.) seeds to liquid nitrogen exposure. CryoLetters. 27(3):169-178, 2006.

ETIENNE, H. et al. Biotechnological applications for the improvement of coffee (Coffea Arabica L.). In Vitro Cellular \& Developmental Biology - Plant, 38 (2):129-138, 2002.

ENGELMANN, F. Plant cryopreservation: progress and prospects. In Vitro Cellular \& Developmental Biology Plant. 40(5):427-433, 2004.

FERREIRA, D. F. Sisvar: A guide for its Bootstrap procedures in multiple comparisons. Ciência e Agrotecnologia. 38(2):109-112, 2014.

FOLGADO, R. et al. Unravelling the effect of sucrose and cold pretreatment on cryopreservation of potato through sugar analysis and proteomics. Cryobiology. 71(3):432-441, 2015.

FUKAI, S.; GOI, M.; TANAKA, M. The chimeric structure of the apical dome of chrysanthemum (Dendranthema grandiflorum (Ramat) Kitam) is affected by cryopreservation. Scientia Horticulturae. 57(4):347-351, 1994.

GALHAUT, L. et al. Seed priming of Trifolium repens L. improved germination and early seedling growth on heavy metalcontaminated soil. Water, Air, and Soil Pollution. 225:1950-1920, 2014.

GONZALEZ-ARNAO, M. T.; ENGELMANN, F. Cryopreservation of plant germplasm using the encapsulation-dehydration technique: Review and case study on sugarcane. CryoLetters. 27(4):155-168, 2006. 
GONZALEZ-ARNAO, M. T. et al. Development and large scale application of cryopreservation techniques for shoot and somatic embryo cultures of tropical crops. Plant Cell, Tissue and Organ Culture. 92(1):1-13, 2008.

KAVIANI, B. Conservation of plant genetic resources by cryopreservation. Australian Journal of Crop Science. 5(6):778-800, 2011.

LIMA, A. E. et al. Desempenho agronômico de populações de cafeeiro do grupo ‘Bourbon'. Coffee Science. 11(1):22-32, 2016.

MASLANKA, M.; PANIS, B.; MALIK, M. Cryopreservation of Narcissus L. "Carlton” somatic embryos by droplet vitrification. Propagation of Ornamental Plants. 16(1):28-35, 2016.

MAZUR, P. Freezing of living cells: mechanisms and implications. American Journal Physiology. 247:125-142; 1984.

MOREIRA, F. C. Dehydration and cryopreservation of Xyris cipoensis seeds. Acta Horticulturae. 1039:243-246, 2014.

MURASHIGE, T.; SKOOG, F. A revised medium for rapid growth and bioassays with tobacco tissue cultures. Physiologia Plantarum. 15:473-497, 1962.

MURTHY, S. M.; TEJAVATHI, D. H. Effect of osmopriming on seed germination and seedling vigour in Microtyloma uniflorum (Lam.) verd c. International Journal of Plant, Animal and Environmental Science. 6(2):71-76, 2016.

NORMAH, M. N.; MAKEEN, A. M. Cryopreservation of excised embryos and embryonic axes. In: REED, B. M. Plant Cryopreservation: A practical guide. New York: Springer, 2007. p.211-220.

PANIS, B.; LAMBARDI, M. Status of cryopreservation technologies in plants (crops and forest trees). In: RUANE, J.; SONNINO, A. The role of biotechnology in exploring and protecting agricultural genetic resources. Rome: Food and Agriculture Organization Of The United Nations, 2006. p.61-78.

PUKACKI P. M.; JUSZCZYK K. Desiccation sensitivity and cryopreservation of the embryonic axes of the seeds of two Acer species. Trees. 29(2):385-396, 2015.

SALAJ, T. Tissue regeneration of Abies embryogenic cell lines after 1 year storage in liquid nitrogen. Biologia.71(1):93-99, 2016.

SEIDEL, G. E. J. Cryopreservation of equine embryos. Veterinary Clinics of North America: Equine Practice. 12(1):85-99, 1996.

SERSHEN, N.; PAMMENTER, N. W.; BERJAK, P. Effects of partial dehydration of recalcitrant Haemanthus montanus zygotic embryos on vigor of recovered seedlings. South Africa Journal of Botany. 77(1):193-202, 2011.
SERSHEN, N. et al. The effects of various parameter s during processing for cryopreservation on the ultrastructure and viability of recalcitrant zygotic embryos of Amaryllis belladonna. Protoplasma. 249(1):155-169, 2011.

SILVA, L. C. et al. Cryopreservation of Byrsonima intermedia embryos followed by room temperature thawing. Acta Scientiarum. 36(3):309-315, 2014.

SILVA, L. C. et al. Shoot-tip cryopreservation by droplet vitrification of Byrsonima intermedia A. JUSS.: a woody tropical and medicinal plant species from Brazilian Cerrado. CryoLetters. 34(4):338-348, 2013

SISUNANDAR, S. et al. Embryo maturity plays an important role for the successful cryopreservation of coconut (Cocos nucifera). In Vitro Cellular \& Developmental Biology Plant. 50(6):688-695, 2014.

SISUNANDAR, S. et al. Dehydration improves cryopreservation of coconut (Cocos nucifera L.). Cryobiology. 61(3):289-296, 2010.

SOUZA, A. C. Dehydration and cryopreservation of Handroanthus serratifolius embryos. Acta Horticulturae. 1039:181-186, 2014.

STEINMACHER, D. A. et al. Cryopreservation of peach palm zygotic embryos. CryoLetters. 28(1):13-22, 2007.

SUZUKI, T. et al. Enhanced formation of roots and subsequent promotion of growth of shoots on cryopreserved nodal segments of asparagus. Cryobiology. 36(3):194-205, 1998.

WESLEY-SMITH, J. et al. Why is intracellular ice lethal? A microscopical study showing evidence of programmed cell death in cryo-exposed embryonic axes of recalcitrant seeds of Acer saccharinum. Annals of Botany. 115(6):9911000, 2015.

WESLEY-SMITH, J. et al. Intracellular ice and cell survival in cryo-exposed embryonic axes of recalcitrant seeds of Acer saccharinum: An ultrastructural study of factors affecting cell and ice structures. Annals of Botany. 113(4):695709, 2014.

WOWK, B. Thermodynamic aspects of vitrification. Cryobiology. 60(1):11-22, 2010.

ZEVALLOS, B. Phenotypic and molecular characterization of plants regenerated from non-cryopreserved and cryopreserved wild Solanum lycopersicum Mill. seeds. CryoLetters. 35(3):216-225, 2014.

ZONTA, J. B. et al. Comparação de metodologias do teste de tetrazólio para sementes de cafeeiro. Idesia. 27(2):17-23, 2009. 